\title{
Chemical Ecology of Red Mangroves, Rhizophora mangle, in the Hawaiian Islands ${ }^{1}$
}

\author{
Brian Fry ${ }^{2,3}$ and Nicole Cormier ${ }^{2,4}$
}

\begin{abstract}
The coastal red mangrove, Rhizophora mangle L., was introduced to the Hawaiian Islands from Florida $100 \mathrm{yr}$ ago and has spread to cover many shallow intertidal shorelines that once were unvegetated mudflats. We used a field survey approach to test whether mangroves at the land-ocean interface could indicate watershed inputs, especially whether measurements of leaf chemistry could identify coasts with high nutrient inputs and high mangrove productivities. During 2001-2002, we sampled mangroves on dry leeward coasts of southern Moloka' $i$ and $\mathrm{O}^{\prime}$ ahu for 14 leaf variables including stable carbon and nitrogen isotopes $\left(\delta^{13} \mathrm{C}, \delta^{15} \mathrm{~N}\right)$, macronutrients $(\mathrm{C}, \mathrm{N}, \mathrm{P})$, trace elements $(\mathrm{B}, \mathrm{Mn}$, $\mathrm{Fe}, \mathrm{Cu}, \mathrm{Zn}$ ), and cations ( $\mathrm{Na}, \mathrm{Mg}, \mathrm{K}, \mathrm{Ca})$. A new modeling approach using leaf $\mathrm{Na}, \mathrm{N}, \mathrm{P}$, and $\delta^{13} \mathrm{C}$ indicated two times higher productivity for mangroves in urban versus rural settings, with rural mangroves more limited by low $\mathrm{N}$ and $\mathrm{P}$ nutrients and high-nutrient urban mangroves more limited by freshwater inputs and salt stress. Leaf chemistry also helped identify other aspects of mangrove dynamics: especially leaf $\delta^{15} \mathrm{~N}$ values helped identify groundwater $\mathrm{N}$ inputs, and a combination of strongly correlated variables $(\mathrm{C}, \mathrm{N}, \mathrm{P}, \mathrm{B}, \mathrm{Cu}, \mathrm{Mg}, \mathrm{K}, \mathrm{Ca})$ tracked the mangrove growth response to nutrient loading. Overall, the chemical marker approach is an efficient way to survey watershed forcing of mangrove forest dynamics.
\end{abstract}

Mangrove coasts are being cleared and developed by humans, and current estimates are that more than $50 \%$ of mangrove forests have been lost already (Ong 1995, Valiela et al.

\footnotetext{
${ }^{1}$ This work was supported in part by the USDA Forest Service, by Louisiana SeaGrant Projects R/CEH13 and R-EFH-07, and by NOAA Multistress award NA 16OP2670. Any use of trade, product, or firm names is for descriptive purposes only and does not imply endorsement by the U.S. Government. Manuscript accepted 4 July 2010.

${ }^{2}$ Institute of Pacific Islands Forestry, Pacific Southwest Research Station, U.S. Department of Agriculture Forest Service, 60 Nowelo Street, Hilo, Hawai'i 96720.

${ }^{3}$ Corresponding author. Current address: Department of Oceanography and Coastal Studies, Louisiana State University, Baton Rouge, Louisiana (e-mail: bfry@ lsu.edu).

${ }^{4}$ Current address: U.S. Geological Survey National Wetlands Research Center, 700 Cajundome Boulevard, Lafayette, Louisiana 70506 (e-mail: cormiern@usgs.gov).
}

Pacific Science (2011), vol. 65, no. 2:219-234

doi: $10.2984 / 65.2 .219$

(C) 2011 by University of Hawai'i Press

All rights reserved
2001). A balance between coastal development and mangrove conservation is being attempted in some areas of the world (Robertson and Phillips 1995, Tam and Wong 2002, Hogarth 2007). Management of smaller forests and stands of mangroves may become important as coastal development intensifies, so it is important to have robust methods for measuring forest condition and development status. Leaf $\mathrm{N}$ and $\mathrm{P}$ generally increase in fertilized red mangroves (Feller 1995, Feller et al. 2002), so higher nitrogen (N) and phosphorus (P) levels in mangrove leaves may help identify areas of nutrient loading and watershed forcing of mangrove growth (Jayasekera 1991, Alongi et al. 1992). Multielement fingerprinting of plant chemistries is now routinely possible (Djingova et al. 2004), and measuring other chemical parameters besides $\mathrm{N}$ and $\mathrm{P}$ to develop multielement profiles of mangrove leaf chemistry was the goal of this study to assist in tracking changes in forest development and productivity.

In this study we examined small stands of mangroves on the Hawaiian islands of 
Moloka'i and O'ahu. The red mangrove, $R b i$ zophora mangle Linnaeus, was introduced to Moloka'i from Florida in the early 1900s to trap watershed soils that were eroding onto nearshore reefs. Since then, the red mangrove has spread extensively on Moloka'i and O'ahu, invading many smaller intertidal areas (Allen 1998, Chimner et al. 2006). Previous studies indicated that $\mathrm{N}$ concentrations and $\delta^{15} \mathrm{~N}$ in mangroves can indicate watershed pollution and locations of $\mathrm{N}$ discharge to the sea (Fry et al. 2000, Costanzo et al. 2003, 2004), especially where background $\mathrm{N}$ and $\delta^{15} \mathrm{~N}$ values are available for nearby areas with low human impact (McKee et al. 2002, Wooller et al. 2003). The mechanism leading to high $\delta^{15} \mathrm{~N}$ values in these and other coastal plants is usually partial denitrification of nitrate from agriculture or sewage in the watershed (Page 1995, McClelland and Valiela 1998, Costanzo et al. 2005), with surviving nitrate enriched in ${ }^{15} \mathrm{~N}$ (Fry et al. 2003). Nitrate passes readily through most watershed soils, and downstream plants that use this nitrate directly or ecosystem-level $\mathrm{N}$ derived from this nitrate also become enriched in ${ }^{15} \mathrm{~N}$ and have high $\delta^{15} \mathrm{~N}$ values (Cole et al. 2004). Plant $\delta^{15} \mathrm{~N}$ can be an early warning indicator for eutrophication where pollutant nitrogen has a high $\delta^{15} \mathrm{~N}$ value (McClelland and Valiela 1998, Fry et al. 2003).

Although high $\delta^{15} \mathrm{~N}$ values in plants are associated generally with coastal eutrophication (Cole et al. 2004), some exceptions have been noted. For example, low $\delta^{15} \mathrm{~N}$ values for plants have been observed in some hypereutrophic systems with very high levels of ammonium (>50 mmol m$~^{-3}$ [Fry et al. 2003]). Possible causes of these lower values include isotope fractionation during plant uptake (McKee et al. 2002) and unprocessed $\mathrm{N}$ inputs with low $\delta^{15} \mathrm{~N}$ values (Fry et al. 2003). Because of these and other occasional observations of relatively low $\delta^{15} \mathrm{~N}$ values for plants in nutrient-rich systems (Costanzo et al. 2003, 2004), we were interested in developing a better calibration of the $\delta^{15} \mathrm{~N}$ plant bioindicator approach for detecting watershed $\mathrm{N}$ pollution. Especially, we wanted to test whether there was a good correspondence between the $\mathrm{N}$ and $\delta^{15} \mathrm{~N}$ indicators, with low values for $\mathrm{N}$ and $\delta^{15} \mathrm{~N}$ in areas with little human impact and high values in areas with high impact. We performed some greenhouse studies to check for possible nitrogen isotope fractionation during mangrove growth (McKee et al. 2002), fractionation that could potentially complicate use of $\delta^{15} \mathrm{~N}$ as a source marker for watershed $\mathrm{N}$ inputs.

We also included other chemical markers besides $\mathrm{N}$ and $\delta^{15} \mathrm{~N}$ to test for coordinated plant responses to watershed forcings and for differences in plant productivity. A previous study used leaf $\mathrm{N}$ and $\delta^{13} \mathrm{C}$ (carbon) to estimate relative productivity for mangroves growing on Kosrae, a Pacific island in the Federated States of Micronesia in the western Pacific (Fry et al. 2009). Although $\delta^{13} \mathrm{C}$ gives an estimate of water use efficiency (Farquhar et al. 1989, Hall et al. 1993), it also can be thought of as a demand/supply ratio governing mangrove use of water and $\mathrm{CO}_{2}$. In this case, multiplying $\delta^{13} \mathrm{C}$ by supply of a growthlimiting nutrient yields:

$$
\begin{aligned}
& \text { Productivity (as demand) } \\
& =\delta^{13} \mathrm{C}^{*} \text { limiting nutrient } \\
& =(\text { demand/supply)*supply. }
\end{aligned}
$$

We parameterized this equation to compare relative productivities of different mangrove trees and mangrove stands in the Hawaiian Islands.

For comparison with this largely theoretical productivity model, we developed a second productivity model based on greenhouse growth studies with red mangroves (Lin and Sternberg 1992). In those studies, mangroves had depressed growth at higher seawater salinities, but the growth depression was alleviated when high levels of nutrients were available to plants. We used field data to parameterize a model that captured this salinity $\times$ nutrients dynamic documented by Lin and Sternberg (1992), with mangrove salt exposure indexed by leaf sodium $(\mathrm{Na})$ (Medina and Francisco 1997). The two models based on $\left(\delta^{13} \mathrm{C}\right.$ and nutrients) and ( $\mathrm{Na}$ and nutrients) gave comparable results and were further validated by initial greenhouse studies and by qualitative field observations. A null hypothesis for the productivity work was that average 

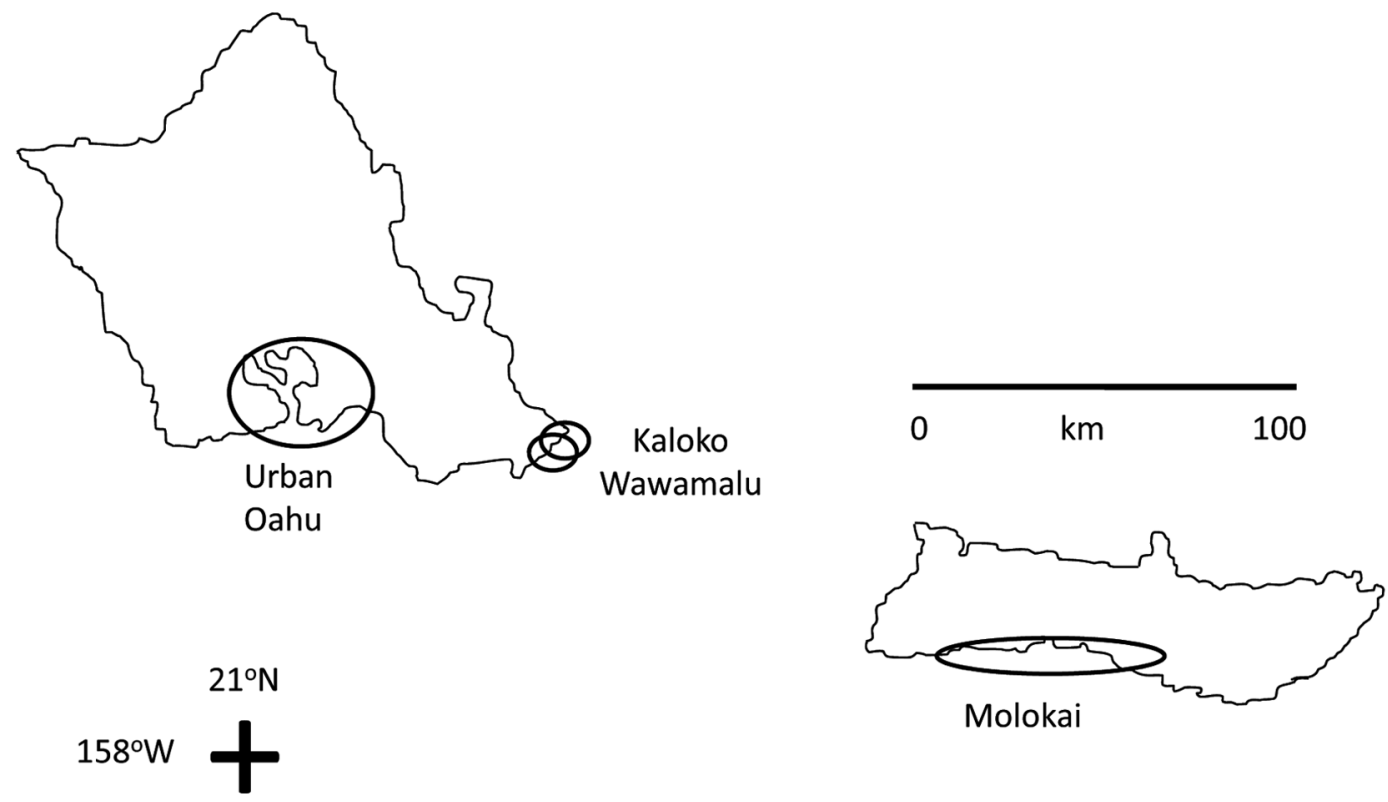

Figure 1. Hawaiian islands of O'ahu and Moloka'i with mangrove sampling sites in four watersheds on the leeward dry sides of the islands.

mangrove productivity was similar at all our study sites.

We tested these ideas by sampling mangroves from multiple locations in four watersheds on the southern leeward (dry) sides of Moloka'i and O'ahu. The locations represented a range of watershed development and human impact, from low-impact sites along the Moloka'i coast and the southeastern tip of

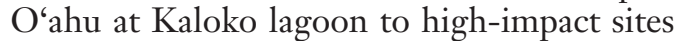
on central O'ahu in urban Honolulu. Watershed inputs to the field sites were estimated qualitatively by observations of human population density and local hillslope development and some nutrient sampling. This general field assessment, along with the work of Laws et al. (1994) on the hypereutrophic nature of urban $\mathrm{O}^{\prime}$ ahu estuaries, led us to rank nutrient inputs as likely greatest for urban O'ahu mangroves, strong for mangroves at an eastern O'ahu Wāwāmalu site where we observed and sampled nutrient-rich groundwater seeps, and low for other forests on rural O'ahu at Kaloko and on Moloka'i. The main goals of the study reported here were to (1) test whether mangrove leaf chemistry could detect distinctive rural versus urban watershed inputs, (2) estimate productivity contrasts in mangroves from rural and urban watersheds, and (3) evaluate $\mathrm{N}$ content and $\delta^{15} \mathrm{~N}$ as specific indicators of watershed $\mathrm{N}$ loading.

\section{MATERIALS AND METHODS}

\section{Study Sites}

During November 2001-July 2002, we collected 73 composite mangrove samples from the four watersheds (Figure 1) as follows: (1) Moloka'i sites were located along the rural southwestern coast of Moloka'i, west of the town of Kaunakakai and downslope of farms and cattle ranches; (2) Kaloko sites were in the clear-water, relatively pristine lagoon facing the open Pacific Ocean on the southeastern tip of O'ahu at Queen's Beach (Melcher et al. 2001). Other than a paved roadway, there was no discernable development in the dry upper reaches of this watershed; (3) Wāwāmalu sites were in a lagoon adjacent to Kaloko to the west. A golf course was directly across the road from the upstream end of the lagoon, 
and housing developments were present farther upslope in the Wāwāmalu drainage; (4) urban O'ahu sites were located in several parts of Honolulu including mangroves from eastern, central, and western parts of the city, respectively, at the Ala Wai canal, Ke'ehi Lagoon, and Pearl Harbor. Uplands adjoining all of the urban $\mathrm{O}^{6}$ ahu sites were highly developed for residential and industrial use.

In each watershed we sampled mangroves across a broad range of field conditions. For example, samples collected at the Kaloko lagoon included plants growing on rocks with little soil, plants from an upper intertidal zone that had a rich organic soil composed of deposited and decomposing mangrove propagules and litter, and plants growing in a tidal creek extending approximately $100 \mathrm{~m}$ north of the central lagoon. Similar broad ranges of conditions were represented in the sampling of other watersheds to allow testing average differences between the watersheds. At two sites (Wāwāmalu on eastern $\mathrm{O}^{\prime}$ ahu and $\mathrm{Ala}$ Wai in central urban Honolulu), we performed some transect sampling along a marine-toland transect to test for progressive changes in leaf chemistry related to watershed inputs.

Mangrove trees generally were 2-5 $\mathrm{m}$ tall at the study sites. Leaf ages were not determined, but studies of red mangroves growing at similar latitudes in Mexico and Florida indicate that leaves are shed throughout the year (reviewed in Ake-Castillo et al. [2006]). Consequently, we estimate that mangrove leaves we sampled were likely $<2 \mathrm{yr}$ old.

Study sites were on the dry, leeward coasts of $\mathrm{O}^{\prime}$ ahu and Moloka'i. Salinity was not measured routinely in this study, but was high and near full-strength seawater (35 psu) except near some shoreline groundwater seeps in Wāwāmalu and at some sites in urban O'ahu where ephemeral streams and wastewater inputs enter the coastal zone.

\section{Leaf Samples}

To obtain representative field composite samples, we collected one mature sun leaf from each of five local trees and pooled the leaves. In the laboratory, leaf petioles were separated from leaves and discarded. Remaining leaf blade tissue was rinsed in deionized water, dried at $60^{\circ} \mathrm{C}$, and ground to a fine powder in an automated mortar and pestle (Wig-LBug). Subsamples were analyzed for stable isotopes $\left(\delta^{13} \mathrm{C}, \delta^{15} \mathrm{~N}\right)$, macronutrients $(\mathrm{C}, \mathrm{N}$, $\mathrm{P})$, cations $(\mathrm{Na}, \mathrm{Mg}, \mathrm{K}, \mathrm{Ca})$, and trace elements (B, Mn, Fe, Cu, Zn). $\mathrm{N}$ and $\mathrm{C}$ concentration and isotopic compositions were determined using a coupled elemental analysis-isotope ratio mass spectrometer system (Brand 1996). Concentrations of P, cations, and trace metals were determined by atomic absorption following acid digestion at the Agricultural Diagnostic Service Center, Sherman Laboratory, at the University of Hawai'i at Mānoa. Concentrations are reported in units of moles $/ \mathrm{kg}, \mathrm{mmol} / \mathrm{kg}$, or $\mu \mathrm{mol} / \mathrm{kg}$ following Medina and Francisco (1997).

To investigate hypothesized $\mathrm{N}$ isotope fractionation during nutrient uptake by red mangroves (McKee et al. 2002), we conducted greenhouse experiments at the University of Hawai'i field station in Waimānalo, Hawai'i, with $R$. mangle propagules collected at the Wāwāmalu lagoon. Propagules were placed in pots with fibrous commercial potting soil, holes in bottoms of pots allowed free drainage of water, and soils were not salty or waterlogged. Plants were watered regularly with an automatic sprinkler system and grew to three to five times initial size over the $1-y r$ period before harvest and sampling. Plants developed stilt roots and produced abundant new leaves during that period. Plants were grown without fertilizer or with fertilizer sprayed every 2 weeks. The fertilizer was a mixture of nitrogen sources and contained 20\% ammonium $\mathrm{N}, 30 \%$ nitrate $\mathrm{N}$, and $50 \%$ urea $\mathrm{N}$. At harvest, five leaves were taken per tree for later laboratory analysis, as described earlier. The greenhouse was well ventilated and exposed to open air at the sides and bottom.

Site differences were evaluated in two ways: (1) significant differences between pairs of mean values were evaluated with two-tailed $t$-tests and the Hochberg's GT2 test when multiple means were involved (Sokal and Rohlf 1997); (2) to provide an overview of the variation in all of 14 plant variables across the four watershed sites, we used a difference 
TABLE 1

Average Chemical Compositions of Mangrove Leaves from Four Sites on O'ahu and Moloka'i, and Relative Enrichment Values for Several Variables

\begin{tabular}{|c|c|c|c|c|c|c|c|c|c|}
\hline \multirow[b]{2}{*}{ Parameter } & \multirow[b]{2}{*}{ Units } & \multicolumn{2}{|c|}{$\begin{array}{c}\text { Urban O'ahu } \\
n=38\end{array}$} & \multicolumn{2}{|c|}{$\begin{array}{c}\text { Wāwāmalu } \\
n=7\end{array}$} & \multicolumn{2}{|c|}{$\begin{array}{c}\text { Kaloko } \\
n=19\end{array}$} & \multicolumn{2}{|c|}{$\begin{array}{c}\text { Moloka'i } \\
n=9\end{array}$} \\
\hline & & Mean & $95 \% \mathrm{CL}$ & Mean & $95 \% \mathrm{CL}$ & Mean & $95 \% \mathrm{CL}$ & Mean & $95 \% \mathrm{CL}$ \\
\hline$\delta^{13} \mathrm{C}_{\mathrm{VPDB}}$ & $\%$ & $-26.4^{\mathrm{A}}$ & 0.4 & $-26.9^{\mathrm{A}, \mathrm{B}}$ & 0.9 & $-26.9^{\mathrm{A}, \mathrm{B}}$ & 0.5 & $-28.2^{\mathrm{B}}$ & 0.8 \\
\hline$\delta^{15} \mathrm{~N}_{\mathrm{AIR}}$ & $\%$ & $5.9^{\mathrm{A}}$ & 0.9 & $11.6^{\mathrm{B}}$ & 2.0 & $2.9^{\mathrm{C}}$ & 1.2 & $4.7^{\mathrm{A}, \mathrm{C}}$ & 1.8 \\
\hline $\mathrm{C}$ & $\mathrm{mol} / \mathrm{kg}$ & $39.3^{\mathrm{A}}$ & 0.4 & $38.2^{\mathrm{A}, \mathrm{B}}$ & 1.0 & $37.0^{\mathrm{B}}$ & 0.6 & $35.2^{\mathrm{C}}$ & 0.9 \\
\hline $\mathrm{N}$ & $\mathrm{mmol} / \mathrm{kg}$ & $1,200^{\mathrm{A}}$ & 58 & $928^{\mathrm{B}}$ & 135 & $697^{\mathrm{C}}$ & 82 & $658^{\mathrm{C}}$ & 119 \\
\hline $\mathrm{P}$ & $\mathrm{mmol} / \mathrm{kg}$ & $40^{\mathrm{A}}$ & 2 & $31^{\mathrm{B}}$ & 4 & $28^{\mathrm{B}}$ & 3 & $33^{\mathrm{B}}$ & 4 \\
\hline B & $\mu \mathrm{mol} / \mathrm{kg}$ & $5,531^{\mathrm{A}}$ & 527 & $8,338^{\mathrm{B}}$ & 1,229 & $9,574^{\mathrm{B}}$ & 746 & $11677^{\mathrm{C}}$ & 1,083 \\
\hline Mn & $\mu \mathrm{mol} / \mathrm{kg}$ & $5,154^{\mathrm{A}}$ & 924 & $3,735^{\mathrm{A}}$ & 2,152 & $5,975^{\mathrm{A}}$ & 1,306 & $4,046^{\mathrm{A}}$ & 1,898 \\
\hline $\mathrm{Fe}$ & $\mu \mathrm{mol} / \mathrm{kg}$ & $2,152^{\mathrm{A}}$ & 196 & $1,526^{\mathrm{A}, \mathrm{B}}$ & 446 & $1,655^{\mathrm{B}}$ & 270 & $2,363^{\mathrm{A}}$ & 393 \\
\hline $\mathrm{Cu}$ & $\mu \mathrm{mol} / \mathrm{kg}$ & $102^{\mathrm{A}}$ & 30 & $196^{\mathrm{A}}$ & 70 & $369^{\mathrm{B}}$ & 42 & $403^{\mathrm{B}}$ & 62 \\
\hline $\mathrm{Zn}$ & $\mu \mathrm{mol} / \mathrm{kg}$ & $92^{\mathrm{A}}$ & 10 & $134^{\mathrm{B}}$ & 24 & $87^{\mathrm{A}}$ & 14 & $118^{\mathrm{A}, \mathrm{B}}$ & 21 \\
\hline $\mathrm{Na}$ & $\mathrm{mmol} / \mathrm{kg}$ & $751^{\mathrm{A}}$ & 108 & $783^{\mathrm{A}}$ & 252 & $835^{\mathrm{A}}$ & 153 & $711^{\mathrm{A}}$ & 222 \\
\hline $\mathrm{Mg}$ & $\mathrm{mmol} / \mathrm{kg}$ & $169^{\mathrm{A}}$ & 17 & $193^{\mathrm{A}}$ & 40 & $332^{\mathrm{B}}$ & 25 & $287^{\mathrm{B}}$ & 36 \\
\hline $\mathrm{K}^{\circ}$ & $\mathrm{mmol} / \mathrm{kg}$ & $180^{\mathrm{A}}$ & 15 & $271^{\mathrm{B}}$ & 34 & $257^{\mathrm{B}}$ & 21 & $256^{\mathrm{B}}$ & 30 \\
\hline $\mathrm{Ca}$ & $\mathrm{mmol} / \mathrm{kg}$ & $154^{\mathrm{A}}$ & 18 & $177^{\mathrm{A}}$ & 43 & $283^{\mathrm{B}}$ & 26 & $322^{\mathrm{B}}$ & 38 \\
\hline $\mathrm{C} / \mathrm{N}$ & molar ratio & $34^{\mathrm{A}}$ & 2 & $42^{\mathrm{B}}$ & 5 & $55^{\mathrm{C}}$ & 3 & $56^{\mathrm{C}}$ & 5 \\
\hline $1000^{*} \mathrm{~N} / \mathrm{C}$ & molar ratio & $31^{\mathrm{A}}$ & 1 & $24^{\text {B }}$ & 3 & $19^{\mathrm{C}}$ & 2 & $19^{\mathrm{C}}$ & 3 \\
\hline $10000^{*} \mathrm{P} / \mathrm{C}$ & molar ratio & $101^{\mathrm{A}}$ & 5 & $82^{\mathrm{B}}$ & 11 & $77^{\mathrm{B}}$ & 7 & $94^{\mathrm{A}, \mathrm{B}}$ & 10 \\
\hline $\mathrm{C} / \mathrm{P}$ & molar ratio & $1,012^{\mathrm{A}}$ & 61 & $1,227^{\mathrm{B}}$ & 141 & $1,367^{\mathrm{B}, \mathrm{C}}$ & 86 & $1,081^{\mathrm{A}, \mathrm{B}}$ & 124 \\
\hline $\mathrm{N} / \mathrm{P}$ & molar ratio & $30^{\mathrm{A}}$ & 2 & $30^{\mathrm{A}}$ & 4 & $26^{\mathrm{A}, \mathrm{B}}$ & 3 & $20^{\mathrm{B}}$ & 4 \\
\hline Relative N & & 1.8 & & 1.4 & & 1.1 & & 1.0 & \\
\hline Relative P & & 1.4 & & 1.1 & & 1.0 & & 1.2 & \\
\hline Relative B & & 1.0 & & 1.5 & & 1.7 & & 2.1 & \\
\hline Relative $\mathrm{Cu}$ & & 1.0 & & 1.9 & & 3.6 & & 3.9 & \\
\hline Relative $\mathrm{Mg}$ & & 1.0 & & 1.1 & & 2.0 & & 1.7 & \\
\hline Relative $\mathrm{K}^{\circ}$ & & 1.0 & & 1.5 & & 1.4 & & 1.4 & \\
\hline Relative $\mathrm{Ca}$ & & 1.0 & & 1.2 & & 1.8 & & 2.1 & \\
\hline
\end{tabular}

Note: Relative enrichment is given as a ratio of the listed average site values = (measured site value/lowest site value). Superscript letters in each row indicate significance groupings, so that averages sharing the same superscript are similar and not significantly different $(P>.05$, Hochberg's GT2 test for differences among means), and averages with different superscripts in each row are significantly different $(P<.05)$.

index (DI) that gives a standardized anomaly versus the overall average (Woodwell et al. 1975, Garten et al. 1977). DI values were calculated as (site average-overall average)/ (overall standard deviation). Errors shown in this paper are $95 \%$ confidence limits unless otherwise stated.

Productivity models were constructed using fractions (ranging from 0 to 1 ) that indicated salt stress and nutrient sufficiency, and these salt and nutrients fractions were calculated from measured values associated with low growth (LG) and high growth (HG):

$$
\mathrm{f}=(\text { sample }-\mathrm{LG}) /(\mathrm{HG}-\mathrm{LG}) \text {. }
$$

Productivity was calculated as:

$$
\text { Productivity }=\mathrm{f}_{\text {SALT }} \times \mathrm{f}_{\text {NUTRIENT }},
$$

with productivity values near 0 indicating little growth and values near 1 indicating maximum growth.

Two models were constructed, the first using $\mathrm{Na}$ to indicate salt stress and $\mathrm{N}$ or $\mathrm{P}$ nutrients to indicate nutrient supply. The second model was identical, except that $\delta^{13} \mathrm{C}$ replaced $\mathrm{Na}$ as the salt stress indicator. In the models, $\mathrm{f}_{\text {NUTRIENT }}$ was evaluated separately for $\mathrm{N}$ and $\mathrm{P}$, and the lower $\mathrm{f}_{\text {NUTRIENT }}$ value was considered the more limiting nutrient and used in 


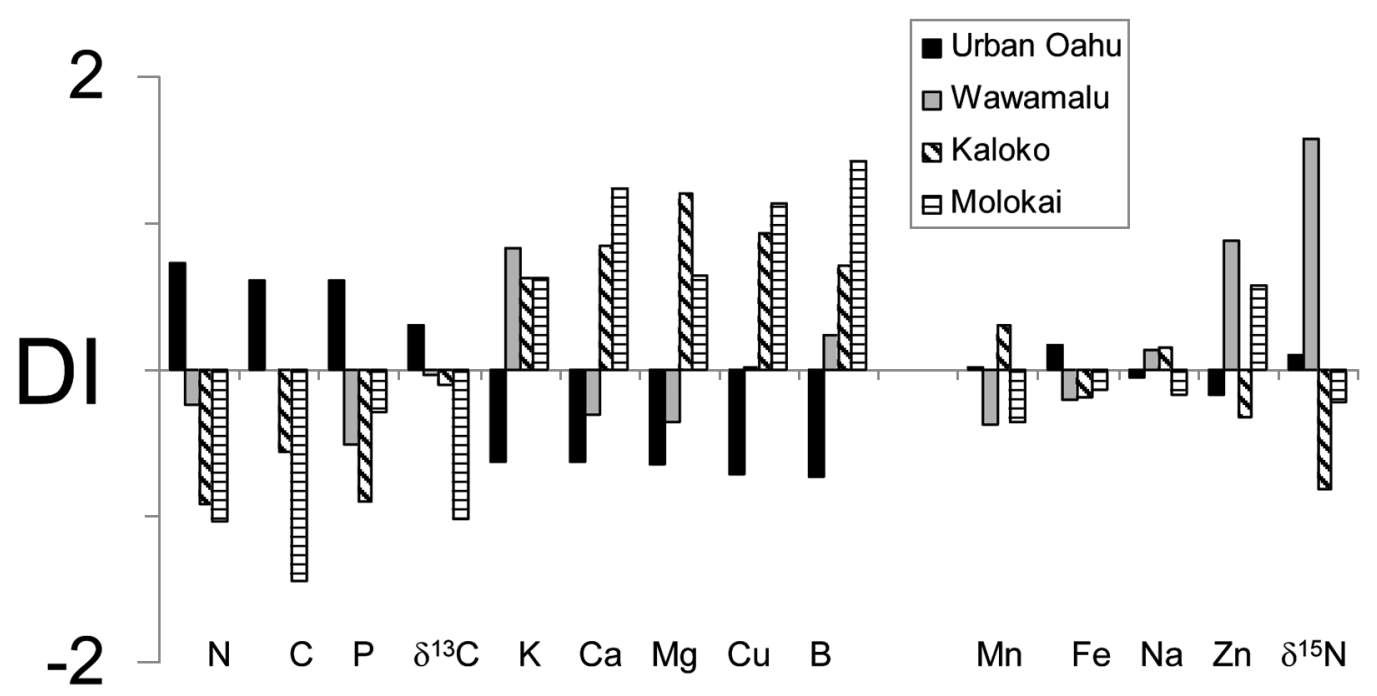

FIgURE 2. Average anomalies (versus overall average set at 0 ) for leaf chemistry at the four watershed sites. Anomalies were calculated as difference index (DI) $=$ (site average - overall average $) /($ overall standard deviation).

the final productivity calculation. Values for low growth (LG) conditions were $1,660 \mathrm{mmol} /$ $\mathrm{kg},-22 \%$ o, $300 \mathrm{mmol} / \mathrm{kg}$, and $10 \mathrm{mmol} / \mathrm{kg}$ for $\mathrm{Na}, \delta^{13} \mathrm{C}, \mathrm{N}$, and $\mathrm{P}$, respectively, and respective values for high growth (HG) conditions were $160 \mathrm{mmol} / \mathrm{kg},-32 \%$ o, $1,800 \mathrm{mmol} / \mathrm{kg}$, and $60 \mathrm{mmol} / \mathrm{kg}$. These LG and HG values represent extreme end-member values mostly measured in this study but also representative of extreme values measured in this and other studies of red mangroves (Feller 1995, Feller et al. 2002, 2003, Fogel et al. 2008). In some cases, end-member values were chosen slightly outside the range of measured values (by $5-10 \%$ or $1 \%$ o-1.25\%o) to center the Hawaiian data to avoid no-growth estimates for field samples.

\section{RESULTS}

\section{Watershed Forcing of Leaf Chemical Patterns}

Mangroves from urban $\mathrm{O}^{`}$ ahu were distinctive in many ways, with especially high average $\mathrm{N}$ and $\mathrm{P}$ nutrient concentrations (Table 1); relative enrichments at urban $\mathrm{O}^{\prime}$ ahu for $\mathrm{N}$ and $\mathrm{P}$ were $1.8 \times$ and $1.4 \times$ those of leaf $\mathrm{N}$ and $\mathrm{P}$ concentrations at background sites (Table
1). In addition to $\mathrm{N}$ and $\mathrm{P}$, several other parameters showed similar extreme high or low values at the urban O'ahu site (Figure 2; extreme values occur for urban $\mathrm{O}^{\prime}$ ahu for the variables $\left.\mathrm{C}, \mathrm{N}, \mathrm{P}, \delta^{13} \mathrm{C}, \mathrm{B}, \mathrm{Cu}, \mathrm{Mg}, \mathrm{K}, \mathrm{Ca}\right)$. The nine variables that distinguished urban O'ahu mangroves were generally strongly intercorrelated (Table 2) as expected for a coordinated chemical growth response. Other variables, notably $\mathrm{Na}$ taken to indicate salinity (Medina and Francisco 1997), were much less correlated with these nine variables (Table 2). Overall the urban O'ahu chemical profile was remarkably distinct from profiles of the other sites that were less affected by anthropogenic forcing (Figure 2).

\section{Productivity}

Productivity calculated from the two models ( $\mathrm{Na}$ and nutrients, $\delta^{13} \mathrm{C}$ and nutrients) gave very similar results (Figure 3 ), with a main result that sun leaf productivity averaged about $2 \times$ higher for urban $\mathrm{O}^{\prime}$ ahu mangroves than at Kaloko, the site with lowest productivities. Productivities for the two other sites were intermediate (Figure 3). Results from the two models were similar because the productivity 
TABLE 2

Pearson Correlation Coefficients for the 73 Measured Field Samples

\begin{tabular}{lcccccccccccccc}
\hline \hline & $\mathrm{C}$ & $\delta^{13} \mathrm{C}$ & $\mathrm{N}$ & $\delta^{15} \mathrm{~N}$ & $\mathrm{P}$ & $\mathrm{K}$ & $\mathrm{Ca}$ & $\mathrm{Mg}$ & $\mathrm{Na}$ & $\mathrm{Fe}$ & $\mathrm{Mn}$ & $\mathrm{Zn}$ & $\mathrm{Cu}$ & $\mathrm{B}$ \\
\hline $\mathrm{C}$ & & 0.25 & 0.67 & $\mathrm{~ns}$ & 0.39 & -0.42 & -0.53 & -0.65 & -0.46 & $\mathrm{~ns}$ & $\mathrm{~ns}$ & $\mathrm{~ns}$ & -0.69 & -0.57 \\
$\delta^{13} \mathrm{C}$ & 0.25 & & $\mathrm{~ns}$ & $\mathrm{~ns}$ & $\mathrm{~ns}$ & -0.38 & -0.44 & -0.32 & 0.33 & $\mathrm{~ns}$ & $\mathrm{~ns}$ & -0.38 & -0.45 & -0.56 \\
$\mathrm{~N}$ & 0.67 & $\mathrm{~ns}$ & & $\mathrm{~ns}$ & 0.62 & -0.52 & -0.67 & -0.73 & $\mathrm{~ns}$ & $\mathrm{~ns}$ & $\mathrm{~ns}$ & $\mathrm{~ns}$ & -0.78 & -0.66 \\
$\delta^{15} \mathrm{~N}$ & $\mathrm{~ns}$ & $\mathrm{~ns}$ & $\mathrm{~ns}$ & & $\mathrm{~ns}$ & $\mathrm{~ns}$ & -0.35 & -0.42 & $\mathrm{~ns}$ & $\mathrm{~ns}$ & -0.23 & 0.25 & -0.27 & $\mathrm{~ns}$ \\
$\mathrm{P}$ & 0.39 & $\mathrm{~ns}$ & 0.62 & $\mathrm{~ns}$ & & -0.44 & -0.31 & -0.37 & $\mathrm{~ns}$ & $\mathrm{~ns}$ & 0.26 & $\mathrm{~ns}$ & -0.43 & -0.49 \\
$\mathrm{~K}$ & -0.42 & -0.38 & -0.52 & $\mathrm{~ns}$ & -0.44 & & 0.49 & 0.49 & $\mathrm{~ns}$ & $\mathrm{~ns}$ & $\mathrm{~ns}$ & 0.35 & 0.56 & 0.61 \\
$\mathrm{Ca}$ & -0.53 & -0.44 & -0.67 & -0.35 & -0.31 & 0.49 & & 0.85 & $\mathrm{~ns}$ & $\mathrm{~ns}$ & 0.44 & $\mathrm{~ns}$ & 0.67 & 0.70 \\
$\mathrm{Mg}$ & -0.65 & -0.32 & -0.73 & -0.42 & -0.37 & 0.49 & 0.85 & & $\mathrm{~ns}$ & $\mathrm{~ns}$ & 0.43 & $\mathrm{~ns}$ & 0.78 & 0.67 \\
$\mathrm{Na}$ & -0.46 & 0.33 & $\mathrm{~ns}$ & $\mathrm{~ns}$ & $\mathrm{~ns}$ & $\mathrm{~ns}$ & $\mathrm{~ns}$ & $\mathrm{~ns}$ & & $\mathrm{~ns}$ & $\mathrm{~ns}$ & $\mathrm{~ns}$ & $\mathrm{~ns}$ & $\mathrm{~ns}$ \\
$\mathrm{Fe}$ & $\mathrm{ns}$ & $\mathrm{ns}$ & $\mathrm{ns}$ & $\mathrm{ns}$ & $\mathrm{ns}$ & $\mathrm{ns}$ & $\mathrm{ns}$ & $\mathrm{ns}$ & $\mathrm{ns}$ & & $\mathrm{ns}$ & $\mathrm{ns}$ & $\mathrm{ns}$ & $\mathrm{ns}$ \\
$\mathrm{Mn}$ & $\mathrm{ns}$ & $\mathrm{ns}$ & $\mathrm{ns}$ & -0.23 & 0.26 & $\mathrm{~ns}$ & 0.44 & 0.43 & $\mathrm{~ns}$ & $\mathrm{~ns}$ & & $\mathrm{~ns}$ & $\mathrm{~ns}$ & $\mathrm{~ns}$ \\
$\mathrm{Zn}$ & $\mathrm{ns}$ & -0.38 & $\mathrm{~ns}$ & 0.25 & $\mathrm{~ns}$ & 0.35 & $\mathrm{~ns}$ & $\mathrm{~ns}$ & $\mathrm{~ns}$ & $\mathrm{~ns}$ & $\mathrm{~ns}$ & & $\mathrm{~ns}$ & 0.23 \\
$\mathrm{Cu}$ & -0.69 & -0.45 & -0.78 & -0.27 & -0.43 & 0.56 & 0.67 & 0.78 & $\mathrm{~ns}$ & $\mathrm{~ns}$ & $\mathrm{~ns}$ & $\mathrm{~ns}$ & & 0.77 \\
$\mathrm{~B}$ & -0.57 & -0.56 & -0.66 & $\mathrm{~ns}$ & -0.49 & 0.61 & 0.70 & 0.67 & $\mathrm{~ns}$ & $\mathrm{~ns}$ & $\mathrm{~ns}$ & 0.23 & 0.77 & \\
\hline
\end{tabular}

Note: ns, not significant $(P>.05)$; values less than -0.3 or greater than 0.3 were significant at $P<.01$; all other values were significant at $.05>P>.01$.

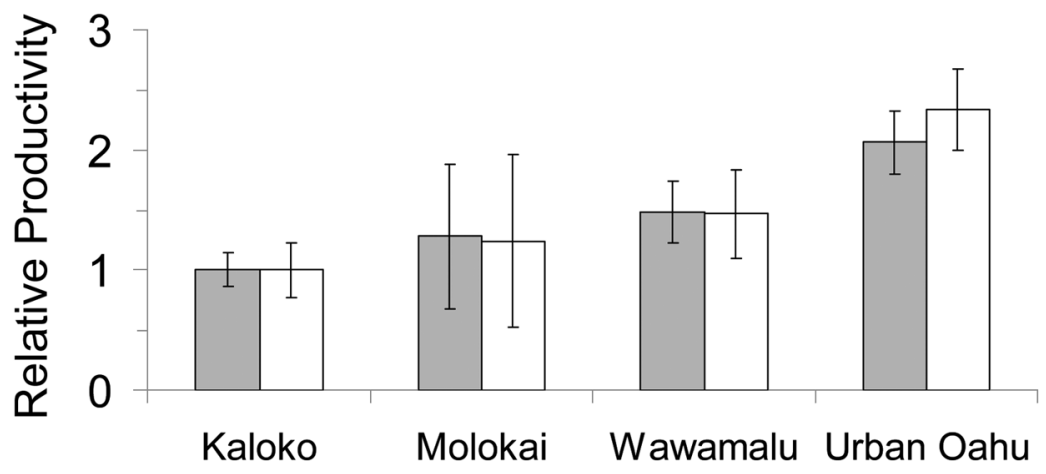

Figure 3. Modeled relative leaf productivities expressed versus the background average value set at Kaloko $=1$. Errors are $95 \%$ confidence limits. Shaded and open bars represent model calculations based respectively on $\left(\delta^{13} \mathrm{C}\right.$ and nutrients) and ( $\mathrm{Na}$ and nutrients) as explained in the text.

estimates were determined mainly by nutrient values that were the same in both models; salt indicators $\left(\mathrm{Na}\right.$ and $\left.\delta^{13} \mathrm{C}\right)$ that differed in the two models showed relatively minor variation across the sites, especially in relation to the much larger nutrient variations (Table 1 ) that largely determined model output. Variation in end-member source values did not substantially change the pattern or magnitude of the relative productivity estimates shown in Figure 3; only substantially decreasing or increasing the modeled importance of nutrient inputs relative to salt stress resulted in a strong change in productivity. For example, if nutrient effects were modeled as half as important as salt stress in controlling productivity, maximum productivity contrasts between sites declined from $2 \times$ (Figure 3 ) to $1.5 \times$. In the remainder of this article, we used the base models of Figure 3 that assumed equal nutrient and salt effects, in accordance with the greenhouse studies of Lin and Sternberg (1992).

Productivity for individual field and greenhouse samples was calculated, with results for samples that had relatively low $\mathrm{N}$ (versus 

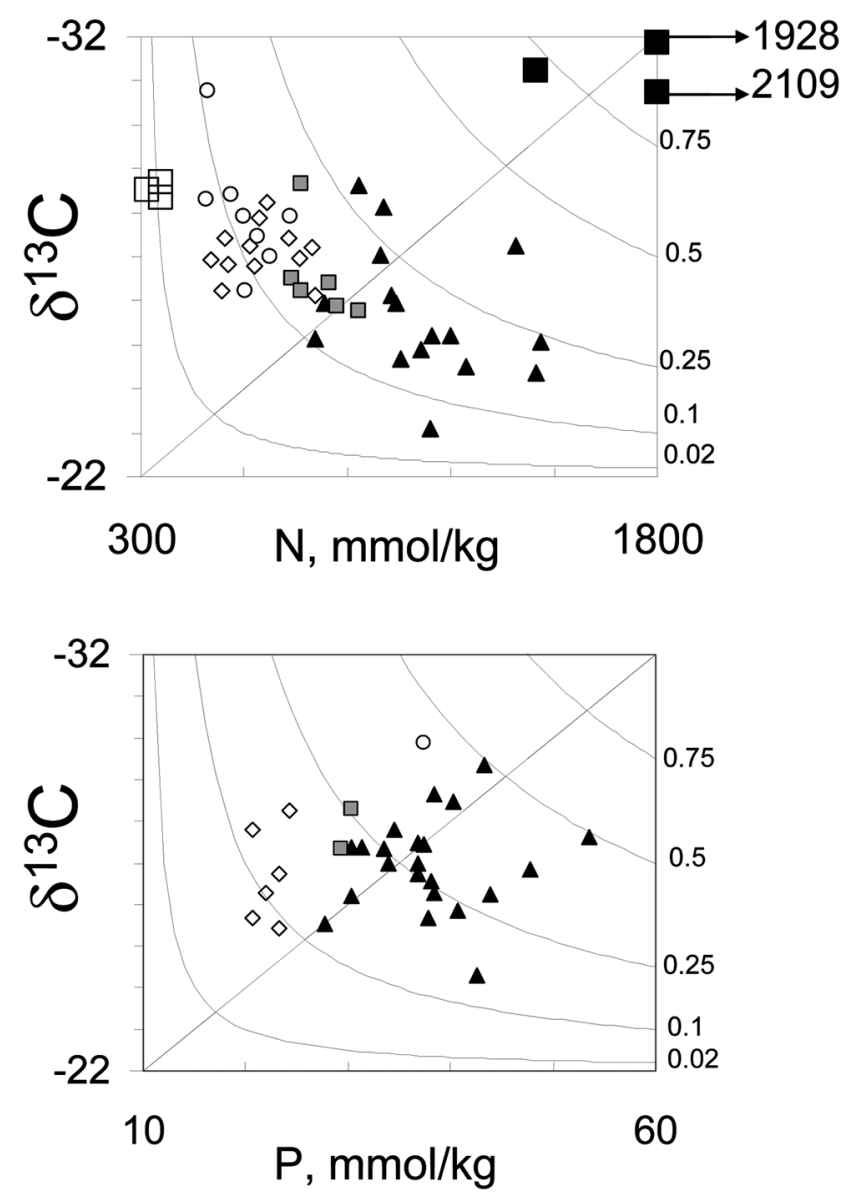

FIgUre 4. Productivity for individual samples in this study, with top panel showing results for samples where $\mathrm{N}$ was relatively more limiting than $\mathrm{P}$, and bottom panel showing results for samples where $\mathrm{P}$ was relatively more limiting than N. Curved isolines give productivities of $0.02,0.1,0.25,0.5$, and 0.75 from lowest left to upper right, respectively. Diagonal lines divide panels into regions of nutrient or salt limitation, with points falling above the diagonal lines indicating mangroves relatively deficient in nutrients and points below the line indicating mangroves relatively salt stressed. Key to symbols: black triangles, urban O'ahu; gray squares, Wāwāmalu; open diamonds, Kaloko; open circles, Moloka'i. Large open squares, greenhouse plants without fertilizer; large closed squares, greenhouse plants with fertilizer, with higher $\mathrm{N}$ contents for two of these plants indicated by arrows.

higher $\mathrm{P}$ in the $\mathrm{f}_{\text {NUTRIENT }}$ comparisons [see Materials and Methods]) shown in the upper panel of Figure 4 and results for samples that had relatively low $\mathrm{P}$ (versus higher $\mathrm{N}$ in $\mathrm{f}_{\text {NUTRIENT }}$ comparisons) shown in the lower panel of Figure 4. Samples sizes are unequal in the two panels of Figure 4 because the data have been divided into relatively $\mathrm{N}$-limited plants (upper panel) and relatively P-limited plants (lower panel). In accordance with expectation that productivity would vary from 0 to 1 for mangroves growing in stressed versus optimal conditions, unfertilized mangroves grown in the greenhouse had very low leaf $\mathrm{N}$ concentrations and low productivities near 0 (Figure 4), presumably because of nearexhaustion of nutrient contained in the initial potting soil. Fertilized mangroves had productivity values near 1.0 (averages for three unfertilized and three fertilized mangroves were, respectively, $0.02 \pm 0.01$ and $0.94 \pm 0.23)$. These greenhouse productivities 
were calculated with $\mathrm{N}$ and $\delta^{13} \mathrm{C}$ only (Figure 4 , top panel); unfortunately greenhouse samples for $\mathrm{P}$ analyses were lost.

Productivity for field samples varied by approximately $10 \times$ (Figure 4 ), from about 0.05 to 0.5 . The rural sites Kaloko and Moloka'i showed relatively more nutrient limitation than salt stress (i.e., values were above the diagonal lines in Figure 4), and the samples from urban $\mathrm{O}^{6}$ ahu often had higher nutrients but did not trend toward a value of 1 characteristic of optimal growth. Instead, urban mangroves with higher leaf nutrients apparently escaped nutrient limitation but encountered limitation by salt stress (i.e., values for these samples were below the diagonal lines in Figure 4). Productivities by watershed averaged $0.12 \pm 0.02,0.15 \pm 0.07,0.18 \pm 0.03$, and $0.24 \pm 0.03$ at Kaloko, Moloka'i, Wāwāmalu, and urban $\mathrm{O}^{\prime} \mathrm{ahu}$, respectively. These average productivities were much less than 1 expected for mangroves growing in optimal conditions and in the greenhouse study, and also much less than 0.5 observed as maximal productivity for some mangroves in this study (Figure 4). The mangroves with 0.5 highest productivi- ties were found growing at the landward head of intertidal creeks and at the edges of golf courses where freshwater supplies and nutrients probably most approached optimal conditions. Higher site variability in productivity at Moloka'i was due to averaging results for large swamp trees with high freshwater supply together with results for smaller coastal trees. Mangroves with lowest $0.06-0.08$ field productivities included small $<1 \mathrm{~m}$ stature plants at Kaloko that had many dead branches and were growing at the edge of salt flats. Leaves from those plants had relatively high $\mathrm{Na}$ and $\delta^{13} \mathrm{C}$ values and low $\mathrm{N}$ concentrations, all indicators of unfavorable growth conditions.

\section{$N$ and $\delta^{15} N$ Indicators of Watershed $N$ Loading}

Nutrient loadings from watersheds are important contributors to site fertility, and we compared leaf nutrient and $\delta^{15} \mathrm{~N}$ as possible indicators of watershed nutrient loading. Leaf $\delta^{15} \mathrm{~N}$ showed a very different pattern than leaf $\mathrm{N}$, with highest values at $\mathrm{W}$ āwāmalu rather than at urban O'ahu (Table 1, Figure 5). There was no continuous increase in $\delta^{15} \mathrm{~N}$ as-

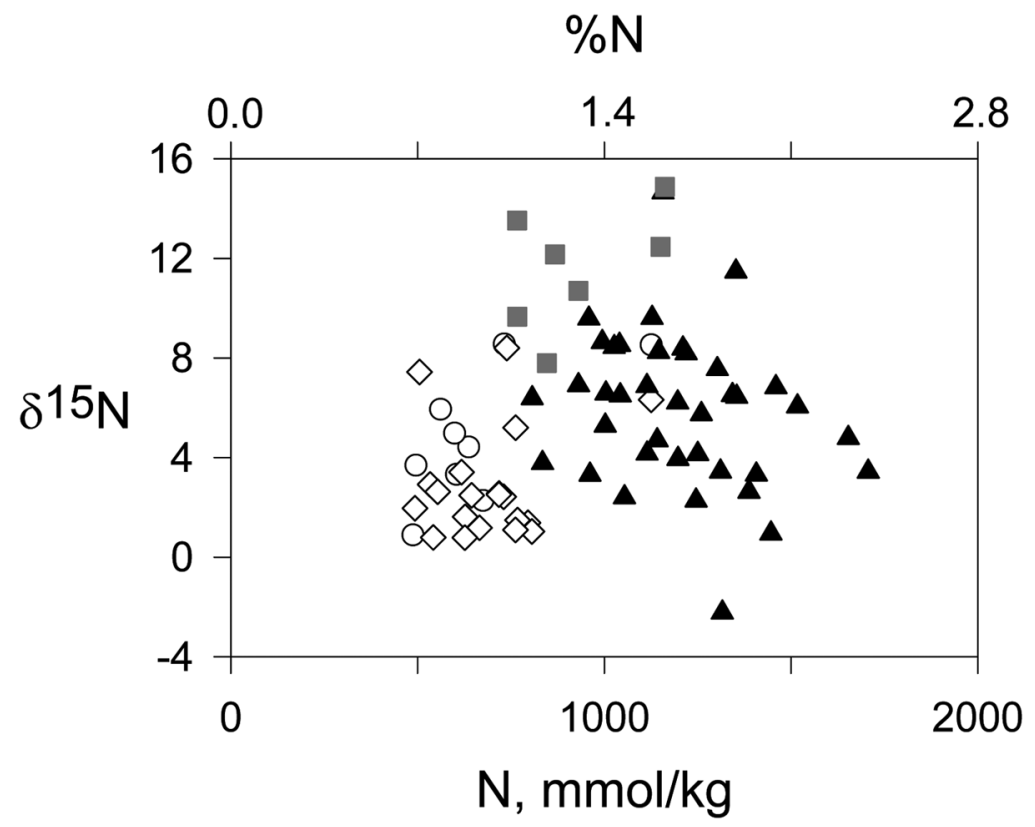

Figure 5. Mangrove leaf $\delta^{15} \mathrm{~N}$ versus leaf $\mathrm{N}$ content for the 73 composite red mangrove field samples analyzed. Symbols as in Figure 4. 
sociated with increasing leaf $\mathrm{N}$ content across the sites, and many samples from urban $\mathrm{O}^{\prime} \mathrm{ahu}$ that had high leaf $\mathrm{N}$ contents had the same relatively low $\delta^{15} \mathrm{~N}$ values $(<4 \%$ o) characteristic of the rural Kaloko and Moloka'i sites (Figure 5).

We examined the $\mathrm{N}$ and $\delta^{15} \mathrm{~N}$ relationships more closely in detailed transect work where we expected increases in both leaf $\mathrm{N}$ and $\delta^{15} \mathrm{~N}$ for mangroves located more inland or upestuary from the mouth of the estuary (i.e., closer to watershed pollution sources). Such $\delta^{15} \mathrm{~N}$ increases were evident in upestuary transects at many sites on $\mathrm{O}^{\prime}$ ahu and Moloka'i, including Middle Loch and West Loch of Pearl Harbor, where mangroves were growing at the edges of golf courses, and on central Moloka'i where mangroves were growing near the effluent from an industrial facility. Figure 6 includes an illustration of one such transect at Wāwāmalu, a site across the road from a golf course. However, the ocean-to-land transect work also showed that the leaf $\mathrm{N}$ content and $\delta^{15} \mathrm{~N}$ did not always increase together in a uniform manner. For example, the urban mangroves from the Ala Wai drainage in Honolulu showed high leaf $\mathrm{N}$ contents along a transect up the northern hillslope (Figure 6) but leaf $\delta^{15} \mathrm{~N}$ values that declined below 7\%o rather than increased (Figure 6). Overall, the transect work indicated a variable relationship between leaf $\mathrm{N}$ contents and $\delta^{15} \mathrm{~N}$.

We did more detailed work at the Wāwāmalu lagoon to investigate possible reasons for the highest leaf $\delta^{15} \mathrm{~N}$ values observed in this study. At low tide, we observed low-salinity $(<10 \mathrm{psu})$ groundwater seeps at the landward edge of the lagoon. Nitrate and phosphate concentrations in seep waters were $>80 \mathrm{mmol} \mathrm{m}^{-3}$ and $>2 \mathrm{mmol} \mathrm{m}^{-3}$, respectively, much elevated in comparison with respective values of $<1$ and $0.1 \mathrm{mmol} \mathrm{m}^{-3}$ that we measured for open-ocean water collected in the adjacent Kaloko lagoon. In addition to the high nutrients, mudflats in the Wāwāmalu seep area were often covered with green macroalgae (Cladophora sp.), and water in the lagoon was opaque. These conditions contrasted sharply with the Kaloko lagoon where bottom rocks and sediments were free of attached
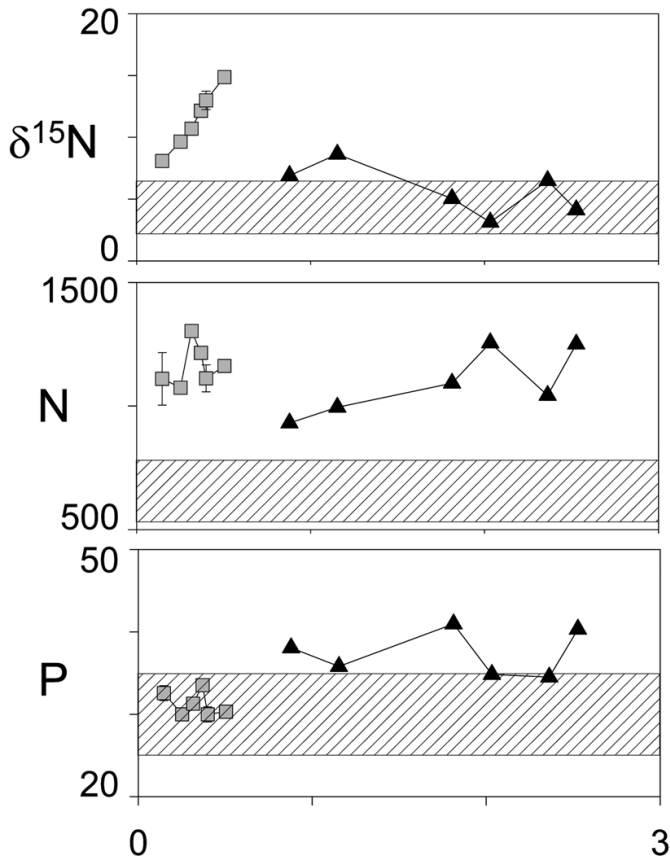

Landward distance from Ocean $(\mathrm{km})$

Figure 6. Mangrove leaf chemistry along two estuarine transects. Distances are plotted inland from the ocean mouth of the estuary at $\mathrm{km}=0$. Black triangles, urban O'ahu at Ala Wai canal and drainage (with strong nutrient loading from channelized runoff); gray squares, Wāwāmalu lagoon (with groundwater inputs). Shaded areas give average values for mangrove leaves from the background control areas (Kaloko and Moloka'i combined, Table 1). All samples are for sun leaves, except for shade leaves results for Ala Wai mangroves at 1.8 and 2.0 $\mathrm{km}$. Values with error bars (SD) are averages of two to four composite samples; other values are single composite samples. Units for depicted leaf $\delta^{15} \mathrm{~N}, \mathrm{~N}$, and $\mathrm{P}$ are \%o, $\mathrm{mmol} / \mathrm{kg}$, and $\mathrm{mmol} / \mathrm{kg}$, respectively.

green algae and waters were clear and of high salinity (35 psu). One-time sampling of the Cladophora beds in the Wāwāmalu lagoon during August 2004 yielded high $\delta^{15} \mathrm{~N}$ values (11\%o) for these Cladophora and 12.6\% for abundant amphipods living in these subtidal attached algae. These results were all consistent with groundwater $\mathrm{N}$ inputs influencing $\mathrm{N}$ dynamics in the Wāwāmalu lagoon.

Greenhouse experiments showed no evidence for significant fractionation of nitrogen isotopes during long-term growth of seedlings. Three red mangrove seedlings grown 
with fertilizer were approximately $2 \times$ larger than five seedlings grown without fertilizer and had $>4 \times$ higher leaf $\mathrm{N}$ contents $(P<.05$, $t$-test), $1,469 \pm 481$ versus $345 \pm 26 \mathrm{mmol}$ $\mathrm{N} / \mathrm{kg}$. The mean leaf $\delta^{15} \mathrm{~N}$ for fertilized trees was $0.4 \pm 0.5 \%$, and the mean leaf $\delta^{15} \mathrm{~N}$ from unfertilized trees was $0.9 \pm 0.6 \%$ o and not significantly different. Unfortunately, samples of the potting soil itself were lost, but mass balance calculations indicated that the extra nitrogen in leaves of fertilized trees averaged $0.25 \%$, a value close to the average $0.35 \%$ o $\delta^{15} \mathrm{~N}$ value measured for the fertilizer.

\section{DISCUSSION}

\section{Watershed Forcing of Leaf Chemical Patterns}

This study showed that four watershed sites had coordinated profiles of chemical variation in mangrove leaves (Figure 2), with landbased nutrient loading likely controlling much of the observed differentiation among sites. Previous studies showed that site variation in chemical parameters is widespread for red mangroves, but explanations of many of these variations are still at an early stage (Lacerda et al. 1993, Medina and Francisco 1997, Medina et al. 2001, Lugo et al. 2007). In some cases, mangrove leaf chemistry seems to directly reflect local soil inputs, but in many other cases mangroves maintain fairly constant chemistry even in the face of widely variable soil conditions (e.g., Zheng et al. 1999). Mangroves thus selectively edit soil inputs of elements and chemicals, presumably to optimize growth. Strong chemical patterns sometimes emerge from these field studies, but further laboratory and field experiments are needed to understand mangrove ecophysiology and the patterns of leaf chemistry found for mangroves growing in different conditions. Especially, laboratory studies could test how nutrients and freshwater inputs control chemical distributions of variables such as $\mathrm{Na}$ (Medina and Francisco 1997), B (Barth 1998, Hauxwell et al. 2001), and K (Cohen and Fong 2006) that may be valuable salinityrelated tracers in work with estuarine macrophytes. Here we focused on a subset of the reported chemical data: how mangrove leaf stable isotope and nutrient measurements may indicate mangrove productivity and nutrient inputs from local watersheds.

\section{Productivity}

Nutrients can limit mangrove growth, but in Hawai' $i$ the measured leaf $\mathrm{N}$ and $\mathrm{P}$ were generally in normal or high ranges reported for red mangroves. For example, leaf $\mathrm{P}$ concentrations at our sites were always $>2 \times$ higher than P-limited red mangroves (Feller 1995). However, leaf $\mathrm{N}$ in several leaf samples from rural sites at Kaloko and Moloka'i was lower than $\mathrm{N}$ concentrations previously documented for N-limited red mangroves (Feller et al. 2002, 2003). Our analysis of leaf nutrient concentrations indicated that either $\mathrm{N}$ or $\mathrm{P}$ could limit mangrove growth at rural $\mathrm{O}^{\prime}$ ahu and Moloka'i background sites, though more samples showed evidence for $\mathrm{N}$ limitation (Figure 4, upper panel) than $\mathrm{P}$ limitation (Figure 4, lower panel). However, at higher nutrient levels encountered in many of the urban mangroves, salt limitation and lack of abundant freshwater supplies seemed limiting. Some field observations were consistent with the importance of freshwater supplies for mangrove growth, especially that $>20 \mathrm{~m}$ tall mangroves are found where freshwater streams are present on the central Moloka' $i$ coast and at He'eia on the windward shore of O'ahu. Sparse rainfall on the dry leeward coasts probably resulted in the strong freshwater limitations indicated for the smaller mangroves encountered in urban $\mathrm{O}^{\prime}$ ahu and throughout this study. Overall, our model productivity calculations based largely on theory and published literature produced results that largely agreed with qualitative field observations of tree height and vigor on $\mathrm{O}^{\prime} \mathrm{ahu}$ and Moloka' $i$. This indicates that our models may capture at least some of the main axes of productivity variation for Hawaiian mangroves.

Nonetheless, the productivity models developed here are simple and likely can be improved with further field calibration. Factors such as nutrient interactions, sulfide levels, root-zone flooding, and porewater hypersalinity can all be important determinants of mangrove growth and performance (Alongi 
2009) but were not included in the models of this study. Implicitly, these other factors were lumped into the nutrient and salt categories to capture the major determinants of mangrove growth. We did not extensively sample mangroves from hypersaline environments or areas that were permanently flooded, and models may need revision to deal with such mangroves. Last, modeled productivity estimates apply to sun leaves, and calculations need some elaboration to arrive at estimates of whole-tree productivity that would include contributions of shade leaves. Estimating shade leaf contributions may be possible in future work because shade leaves have lower $\delta^{13} \mathrm{C}$ values than sun leaves (Farquhar et al. 1989), and wood or bark $\delta^{13} \mathrm{C}$ samples may integrate the whole-tree contributions of sun + shade leaves (Fry et al. 2009). Elaborating and testing the simple models of this study may be worthwhile for future tracking of mangrove productivity, and the (nutrient and $\delta^{13} \mathrm{C}$ ) model also may apply generally to $\mathrm{C}_{3}$ plants in many systems where nutrients and water are major determinants of plant growth. For example, results given in Cordell et al. (1999) for an upland Hawaiian tree are consistent with the (nitrogen and $\delta^{13} \mathrm{C}$ ) model used here (Figure 4) for estimating plant productivity.

\section{$N$ and $\delta^{15} N$ Indicators of Watershed $N$ Loading}

Low $\delta^{15} \mathrm{~N}$ values in the $-2 \%$ o to $+3 \%$ o range were indicative of background conditions in this study and in previous mangrove studies (Fry et al. 2000, Fry and Smith 2002, Smallwood et al. 2003, Wooller et al. 2003, Muzuka and Shunula 2006). These low values in coastal mangrove systems probably reflect long-term nitrogen fixation inputs near $0 \%$ (Fogel et al. 2008) as well as inputs of marine nitrate (Dore et al. 2002). Much higher $\delta^{15} \mathrm{~N}$ values $>10 \%$ are generally associated with anthropogenic wastewater inputs, especially via groundwater (Page 1995, Cole et al. 2004; this study). A surprising result was that low $\delta^{15} \mathrm{~N}$ values $(<10 \%$ o) were found in many plants from urban Honolulu where high leaf $\mathrm{N}$ and $\mathrm{P}$ concentrations were consistent with strong anthropogenic inputs.
In urban Honolulu, it is possible that mangroves had relatively low $1 \%$ o- $-10 \%$ o $\delta^{15} \mathrm{~N}$ values because nutrients had low $\delta^{15} \mathrm{~N}$, with rapid freshwater runoff not allowing enough time for microbial use and ${ }^{15} \mathrm{~N}$ enrichment in dissolved inorganic nitrogen (DIN) pools of ammonium and nitrate. We hypothesize that rapid microbial processing of DIN with accompanying ${ }^{15} \mathrm{~N}$ enrichment might be the general rule in warm tropical watersheds where mangroves are abundant, with some exceptions where there is channelized drainage for storm runoff. Channelized urban drainage can promote extreme nutrient loading of coastal systems, as Laws et al. (1994) documented for the Ala Wai canal in urban Honolulu. Low to moderate $\delta^{15} \mathrm{~N}$ values often result for aquatic particulate organic matter in these systems, though dilution is strong during tidal mixing with offshore waters (Laws et al. 1999, Parnell 2001). Thus, the moderate $3 \%$ o $-8 \%$ o $\delta^{15} \mathrm{~N}$ values of the Ala Wai mangroves sampled in this study (Figure 6) occurred in an area of strong channelized surface runoff, rather than in an area of slow groundwater seepage. Rapid runoff may account for moderate plant $\delta^{15} \mathrm{~N}$ occasionally observed in this and other estuaries with strong agricultural and urban inputs (Costanzo et al. 2003, Fry et al. 2003). In those cases, plant $\delta^{15} \mathrm{~N}$ often approaches background values, and leaf $\mathrm{N}$ content may be a better indicator of $\mathrm{N}$ inputs than $\delta^{15} \mathrm{~N}$.

Another possible explanation of low $\delta^{15} \mathrm{~N}$ in mangroves is isotope fractionation during plant N uptake (Fry et al. 2000, McKee et al. 2002). However, evidence for fractionation and low $\delta^{15} \mathrm{~N}$ in red mangroves has only been reported for stunted mangroves growing in P-deficient conditions (McKee et al. 2002). Most mangroves of this study did not exhibit those very low P levels, and our greenhouse experiments showed that mangroves had similar $\delta^{15} \mathrm{~N}$ values to fertilizer $\mathrm{N}$ without isotopic fractionation. Nonetheless, further greenhouse studies are needed to assess possible fractionation during $\mathrm{N}$ acquisition by red mangroves (Fogel et al. 2008), especially experiments with high ammonium in porewaters to more closely simulate field conditions. 
Regardless of the mechanism that leads to low $\delta^{15} \mathrm{~N}$ in urban mangroves, a conclusion from these observations is that using mangroves to detect and monitor $\mathrm{N}$ inputs can succeed but is best approached with both $\mathrm{N}$ and $\delta^{15} \mathrm{~N}$. The $\delta^{15} \mathrm{~N}$ indicator was useful in many situations and generally seems to function well as an early warning indicator of the onset of watershed $\mathrm{N}$ loading from groundwaters (Page 1995, McClelland and Valiela 1998). However, N content was the better indicator in high $\mathrm{N}$ conditions pertaining at urban $\mathrm{O}^{\prime}$ ahu in this study. Future survey work could take a more sample-intensive bottomup approach to $\mathrm{N}$ loading problems, including sampling groundwater and runoff nutrients as well as mangroves. Groundwater nutrient inputs can be locally very important in many estuarine systems, including those in the Hawaiian Islands (Dollar and Atkinson 1992, Garrison et al. 2003).

In summary, measuring leaf chemistry offers a tracer-based way of viewing forest dynamics, with many more chemicals possible to measure than those assayed in this study (e.g., DeCarlo and Spencer 1997, Djingova et al. 2004). Future greenhouse experiments could help calibrate controls of red mangrove leaf chemistry, so that leaf chemistry measured in field samples would reliably indicate influences of salinity, nutrients, water, and sunlight on mangrove growth and ecology. Adopting a tracer-based way of using the trees to see the forest should help scientists and managers better understand how mangrove forests develop and change in response to watershed development, perturbation, and restoration. This study used this emergent chemical marker approach to provide several new findings: (1) urban Hawaiian red mangroves had a distinctive profile of chemical markers compared with profiles for mangroves from rural settings; (2) watershed nutrient inputs were not always recorded by elevated $\delta^{15} \mathrm{~N}$ values but were best traced by a combination of markers that included other measurements, especially of leaf $\mathrm{N}$ and seep nitrate; (3) Hawaiian mangrove stands on the dry leeward coasts of $\mathrm{O}^{6}$ ahu and Moloka' $i$ that were fertilized by watershed nutrients and freshwater may have doubled sun leaf produc- tivity compared with background conditions; (4) models could be used to estimate nutrient versus freshwater limitations of mangrove growth (for example, low freshwater supply in the urban Honolulu watershed likely limited further productivity increases for mangroves growing in high nutrient conditions).

\section{ACKNOWLEDGMENTS}

We thank Brian Popp and Terri Rust for help with $\mathrm{C}$ and $\mathrm{N}$ measurements. Mike Parsons and Tracy Wiegner commented on and improved early versions of the manuscript; comments from anonymous reviewers also improved the manuscript. We thank Jim Baldwin of the USDA Forest Service for his expert statistical advice and assistance.

\section{Literature Cited}

Ake-Castillo, J. A., G. Vazquez, and J. LopezPortillo. 2006. Litterfall and decomposition of Rbizophora mangle L. in a coastal lagoon in the southern Gulf of Mexico. Hydrobiologia 559:101-111.

Allen, J. A. 1998. Mangroves as alien species: The case of Hawaii. Glob. Ecol. Biogeogr. Lett. 7:61-71.

Alongi, D. M. 2009. The energetics of mangrove forests. Springer, New York.

Alongi, D. M., K. G. Boto, and A. I. Robertson. 1992. Nitrogen and phosphorus cycles. Pages 251-292 in A. I. Robertson and D. M. Alongi, eds. Tropical mangrove ecosystems. American Geophysical Union, Washington, D.C.

Barth, S. 1998. ${ }^{11} \mathrm{~B} /{ }^{10} \mathrm{~B}$ variations of dissolved boron in a freshwater-seawater mixing plume (Elbe Estuary, North Sea). Mar. Chem. 62:1-14.

Brand, W. A. 1996. High precision isotope ratio monitoring techniques in mass spectrometry. J.Mass Spectrosc. 31:225-235.

Chimner, R. A., B. Fry, M. Y. Kaneshiro, and N. Cormier. 2006. Current extent and historical expansion of introduced mangroves on O'ahu, Hawai'i. Pac. Sci. 60:377-383.

Cohen, R. A., and P. Fong. 2006. Using opportunistic green macroalgae as indicators 
of nitrogen supply and sources to estuaries. Ecol. Appl. 16:1405-1420.

Cole, M. L., K. D. Kroeger, J. W. McClelland, and I. Valiela. 2004. Macrophytes as indicators of land-derived wastewater: Application of a $\delta^{15} \mathrm{~N}$ method in aquatic systems. Water Resour. Res. 41:W01014.

Cordell, S., G. Goldstein, F. C. Meinzer, and L. L. Handley. 1999. Allocation of nitrogen and carbon in leaves of Metrosideros polymorpha regulates carboxylation capacity and $\delta^{13} \mathrm{C}$ along an altitudinal gradient. Funct. Ecol. 13:811-818.

Costanzo, S. D., M. J. O'Donohue, and W. C. Dennison. 2003. Assessing the seasonal influence of sewage and agricultural nutrient inputs in a subtropical estuary. Estuaries 26:857-865.

2004. Assessing the influence and distribution of shrimp pond effluent in a tidal mangrove creek in north-east Australia. Mar. Pollut. Bull. 48:514-525.

Costanzo, S. D., J. Udy, B. Longstaff, and A. Jones. 2005. Using nitrogen stable isotope ratios $\left(\delta^{15} \mathrm{~N}\right)$ of macroalgae to determine the effectiveness of sewage upgrades: Changes in the extent of sewage plumes over four years in Moreton Bay, Australia. Mar. Pollut. Bull. 51:212-217.

DeCarlo, E. H., and K. J. H. Spencer. 1997. Retrospective analysis of anthropogenic inputs of lead and other heavy metals to the Hawaiian sedimentary environment. Appl. Organomet. Chem. 11:415-437.

Djingova, R., I. Kuleff, and B. Markert. 2004. Chemical fingerprinting of plants. Ecol. Res. 19:3-11.

Dollar, S. J., and M. J. Atkinson. 1992. Effect of nutrient subsidies from groundwater to nearshore marine ecosystems off the island of Hawaii. Estuarine Coastal Shelf Sci. 35:409-424.

Dore, J. E., J. R. Brum, L. M. Tupas, and D. M. Karl. 2002. Seasonal and interannual variability in sources of nitrogen supporting export in the oligotrophic subtropical North Pacific Ocean. Limnol.Oceanogr. 47:1595-1607.

Farquhar, G. D., J. R. Ehleringer, and K. T. Hubick. 1989. Carbon isotope discrim- ination and photosynthesis. Annu. Rev. Plant Physiol. Plant Mol. Biol. 40:503537.

Feller, I. C. 1995. Effects of nutrient enrichment on growth and herbivory of dwarf red mangrove (Rbizophora mangle). Ecol. Monogr. 65:477-505.

Feller, I. C., K. L. McKee, D. F. Whigham, and J. P. O’Neill. 2002. Nitrogen vs. phosphorus limitation across an ecotonal gradient in a mangrove forest. Biogeochemistry (Dordr.) 62:145-175.

Feller, I. C., D. F. Whigham, K. L. McKee, and C. E. Lovelock. 2003. Nitrogen limitation of growth and nutrient dynamics in a disturbed mangrove forest, Indian River Lagoon, Florida. Oecologia (Berl.) 134:405-414.

Fogel, M. L., M. J. Wooller, J. Cheeseman, B. J. Smallwood, Q. Roberts, I. Romero, and M. Jacobson Meyers. 2008. Unusually negative nitrogen isotopic compositions $\left(\delta^{15} \mathrm{~N}\right)$ of mangroves and lichens in an oligtrophic, microbially-influenced ecosystem. Biogeosci. Disc. 5:937-969.

Fry, B., A. L. Bern, M. S. Ross, and J. F. Meeder. 2000. $\delta^{15} \mathrm{~N}$ studies of nitrogen use by the red mangrove Rhizophora mangle $\mathrm{L}$. in South Florida. Coastal Estuarine Sci. 50:291-296.

Fry, B., N. Cormier, and A. W. J. Demopoulos. 2009. Adventures in an isotopically ordered world: The chemical ecology of Micronesian mangroves and crabs. Pages 50-56 in N. Yoshida, ed. Proceedings of the 4th International Conference on Isotopomers, ISI2008-18.

Fry, B., A. Gace, and J. W. McClelland. 2003. Chemical indicators of anthropogenic nitrogen loading in four Pacific estuaries. Pac. Sci. 57:77-101.

Fry, B., and T. J. Smith III. 2002. Stable isotope studies of red mangroves and filter feeders from the Shark River estuary, Florida. Bull. Mar. Sci. 70:871-890.

Garrison, G. H., C. R. Glenn, and G. M. McMurtry. 2003. Measurement of submarine groundwater discharge in Kahana Bay, O‘ahu, Hawai'i. Limnol. Oceanogr. 48:920-928. 
Garten, C. T., Jr., J. B. Gentry, and R. R. Sharitz. 1977. An analysis of elemental concentrations in vegetation bordering a southeastern United States coastal plain ecosystem. Ecology 58:979-992.

Hall, A. E., J. R. Ehleringer, and G. D. Farquhar. 1993. Stable isotopes and plant carbon-water relations. Academic Press, San Diego.

Hauxwell, A. M., C. Neill, I. Valiela, and K. D. Kroeger. 2001. Small-scale heterogeneity of nitrogen concentrations in groundwater at the seepage face of Edgartown Great Pond. Biol. Bull. (Woods Hole) 201:292-294.

Hogarth, P. 2007. The biology of mangroves and seagrasses. Oxford University Press, Oxford, United Kingdom.

Jayasekera, R. 1991. Chemical composition of the mangrove Rhizophora mangle L. J. Plant Physiol. 138:119-121.

Lacerda, L. D., C. E. V. Carvalho, K. F. Tanizaki, A. R. C. Ovalle, and C. E. Rezende. 1993. The biogeochemistry and trace metals distribution of mangrove rhizospheres. Biotropica 25:252-257.

Laws, E. A., J. Hiraoka, M. Mura, B. Punu, T. Rust, S. Vink, and C. Yamamura. 1994. Impact of land runoff on water-quality in an Hawaiian estuary. Mar. Environ. Res. 38:225-241.

Laws, E. A., D. Ziemann, and D. Schulman. 1999. Coastal water quality in Hawaii: The importance of buffer zones and dilution. Mar. Environ. Res. 48:1-21.

Lin, G., and L. d. S. L. Sternberg. 1992. Effect of growth form, salinity, nutrient and sulfide on photosynthesis, carbon isotope discrimination and growth of red mangrove (Rbizophora mangle L.). Aust. J. Plant Physiol. 19:509-517.

Lugo, A. E., E. Medina, E. Cuevas, G. Cintrón, E. N. Laboy Nieves, and Y. Schaeffer Novelli. 2007. Ecophysiology of a mangrove forest in Jobos Bay, Puerto Rico. Caribb. J. Sci. 43:200-219.

McClelland, J. W., and I. Valiela. 1998. Linking nitrogen in estuarine producers to land-derived sources. Limnol. Oceanogr. 43:577-585.
McKee, K. L., I. C. Feller, M. Popp, and W. Wanek. 2002. Mangrove isotopic fractionation $\left(\delta^{15} \mathrm{~N}, \delta^{13} \mathrm{C}\right)$ across a nitrogen vs. phosphorus limitation gradient. Ecology 83:1065-1075.

Medina, E., and M. Francisco. 1997. Osmolality and $\delta^{13} \mathrm{C}$ of leaf tissues of mangrove species from environments of contrasting rainfall and salinity. Estuarine Coastal Shelf Sci. 45:337-344.

Medina, E., T. Giarrizzo, M. Menezes, M. Carvalho Lira, E. A. Carvalho, A. Peres, B. A. Silva, R. Vilhena, A. Reise, and F. C. Braga. 2001. Mangal communities of the "Salgado Paraense": Ecological heterogeneity along the Braganca peninsula assessed through soil and leaf analyses. Amazoniana 16:397-416.

Melcher, P. J., G. Goldstein, F. C. Meinzer, D. E. Yount, T. J. Jones, N. M. Holbrook, and C. X. Huang. 2001. Water relations of coastal and estuarine Rhizophora mangle: Xylem pressure potential and dynamics of embolism formation and repair. Oecologia (Berl.) 126:182-192.

Muzuka, A. N. N., and J. P. Shunula. 2006. Stable isotope compositions of organic carbon and nitrogen of two mangrove stands along the Tanzanian coastal zone. Estuarine Coastal Shelf Sci. 66:447-458.

Ong, J. E. 1995. The ecology of mangrove conservation and management. Hydrobiology 295:343-351.

Page, H. M. 1995. Variation in the natural abundance of ${ }^{15} \mathrm{~N}$ in the halophyte Salicornia virginica, associated with groundwater subsidies of nitrogen in a southern California salt marsh. Oecologia (Berl.) 104:181188.

Parnell, P. E. 2001. The distribution of estuarine and oceanic water masses on the southern shore of $\mathrm{O}^{\prime} \mathrm{ahu}$, Hawai'i: Ecological and coastal management implications, and novel methodology. Limnol. Oceanogr. 46:1468-1485.

Robertson, A. I., and M. J. Phillips. 1995. Mangroves as filters of shrimp pond effluent: Predictions and biogeochemical research needs. Hydrobiology 295:311321. 
Smallwood, B. J., M. J. Wooller, M. E. Jacobson, and M. L. Fogel. 2003. Isotopic and molecular distributions of biochemicals from fresh and buried Rhizophora mangle leaves. Geochem. Trans. 4:3846.

Sokal, R. R., and F. J. Rohlf. 1997. Biometry. W. H. Freeman and Company, New York.

Tam, N. F. Y., and Y. S. Wong. 2002. Conservation and sustainable exploitation of mangroves in Hong Kong. Trees: Struct. Funct. 16:224-229.

Valiela, I., J. L. Bowen, and J. K. York. 2001. Mangrove forests: One of the world's threatened major tropical environments. BioScience 51:807-815.
Woodwell, G. M., R. H. Whittaker, and R. A. Houghton. 1975. Nutrient concentrations in plants in the Brookhaven oak-pine forest. Ecology 56:318-332.

Wooller, M., B. Smallwood, M. Jacobson, and M. Fogel. 2003. Carbon and nitrogen stable isotopic variation in Laguncularia racemosa (L.) (white mangrove) from Florida and Belize: Implications for trophic level studies. Hydrobiologia 499:1323.

Zheng, W.-J., W.-Q. Wang, and P. Lin. 1999. Dynamics of element contents during the development of hypocotyls and leaves of certain mangrove species. J. Exp. Biol. Ecol. 233:247-257. 